\title{
Organic Glues or Fibrin Glues from Pooled Plasma: Efficacy, Safety and Potential as Scaffold Delivery Systems
}

\author{
Clémence Tabélé ${ }^{1}$, Marc Montana ${ }^{2}$, Christophe Curti ${ }^{2-3}$, Thierry Terme ${ }^{2}$, Pascal Rathelot ${ }^{2-3}$, Sophie Gensollen ${ }^{1}$, Patrice \\ Vanelle 2-3 $^{2-19}$ \\ ${ }^{1}$ Service de la pharmacie à usage intérieur de l'hôpital de la Conception, Marseille, France \\ ${ }^{2}$ Aix-Marseille Univ, CNRS, Institut de Chimie Radicalaire ICR, UMR 7273, Laboratoire de Pharmaco-Chimie \\ Radicalaire, Marseille, France \\ ${ }^{3}$ Assistance Publique - Hôpitaux de Marseille (AP-HM), Service Central de la Qualité et de l'Information \\ Pharmaceutiques SCQIP, Marseille, France
}

Received, October 11, 2011; Revised, January 5, 2012; Accepted, January 16, 2011; Published, January 17, 2011.

\begin{abstract}
Since 1976, fibrin glues have been attracting medical interest, spreading from their initial use as a hemostatic agent in cardiovascular surgery to other fields of surgery. Studies have compared the efficacy of fibrin glues vs sutures in surgery. However, few comparisons have been made of the efficacy and safety of the different fibrin glues commercially available. Recently, fibrin glues have been tested as a scaffold delivery system for various substances inside the body (drugs, growth factors, stem cells). The infectious risk (viruses, new germs) of this blood-derived product was also studied in assays on viral inactivation methods. The development of autologous fibrin glues offers a solution to the problem of infectious risk. This review examines the current state of knowledge on the efficacy, safety and future potential of fibrin glues.
\end{abstract}

This article is open to POST-PUBLICATION REVIEW. Registered readers (see "For Readers") may comment by clicking on ABSTRACT on the issue's contents page.

\section{INTRODUCTION}

Fibrin has been described as a hemostatic agent for more than 100 years, but it has only been used in humans since the 1960s. It was initially marketed in the late 1970s to promote hemostasis as a suture support in surgery, or to provide wound sealing when bleeding cannot be controlled using conventional methods. Fibrin glues are mainly extracted from pooled plasma and contain different amounts of purified and virally inactivated human proteins: fibrinogen, thrombin, factor XIII (F XIII), anti-fibrinolytic agents and calcium chloride (1). The glues mimic the last step of the physiologic blood coagulation cascade to form a fibrin clot, hence providing early hemostasis on the treated area.

Fibrin glues are usually prepared from whole blood by cryoprecipitation, followed by two-step viral inactivation/removal. Because fibrin glues from pooled plasma are plasma-derived products, their use exposes the receiver to the risk of pathogen transmission from the donor blood. Over the last thirty years, various studies have assessed the efficacy and the safety of fibrin glues.

Prospective applications for autologous fibrin glues include replacing fibrin glues from pooled plasma, since autologous glues offer advantages like no risk of infection or hypersensitivity.

This review highlights, in addition to the conventional applications, potential applications of the glues in areas such as scaffold delivery of drugs and other substances.

\section{ROLE OF FIBRIN GLUES IN THE COAGULATION CASCADE}

\section{Coagulation cascade}

Physiologic blood clotting leads to synthesis of fibrinogen, a glycoprotein containing three dimers of polypeptides ( $2 \mathrm{~A} \alpha, 2 \mathrm{~B} \beta$ et $2 \gamma$ ) linked to each other by disulfide bonds. Fibrinogen is cleaved by thrombin to release fibrin and two fibrinopeptides $\mathrm{A}$ and $\mathrm{B}(\mathrm{FpA}, \mathrm{FpB})$. Then, the soluble fibrin monomers polymerize spontaneously thanks to hydrogen bonds, forming an insoluble and stable fibrin polymer. F XIII (zymogen activated by thrombin in the presence of calcium into a transglutaminase) catalyzes the formation of covalent bonds between fibrin chains, to stabilize

\footnotetext{
Correspondance Author: Marc Montana, Aix-Marseille Univ, CNRS, Institut de Chimie Radicalaire ICR, UMR 7273, Laboratoire de Pharmaco-Chimie Radicalaire, Faculté de Pharmacie, 27 Boulevard Jean Moulin, 13385 Marseille Cedex 05, France E-mail : marc.montana@univ-amu.fr
} 
and to strengthen the mechanical stability of the fibrin clot and to enhance its resistance to clot lysis. During fibrinolysis, plasmin cleaves fibrin into 5 fibrin degradation products (FDPs). The mechanism of the action of fibrin glues is now well established $(1,2)$. Fibrin glues echo the last step of blood clotting, operating separately from the physiologic coagulation mechanism. This enables fibrin glues to be used in treating patients with coagulopathy (3-7).

A double-syringe system (fitted with a cannula), containing both the fibrinogen component and the thrombin component separated into two different channels, is used to apply the glue: the two components are externally mixed at the tip of the cannula, on the wound (8).

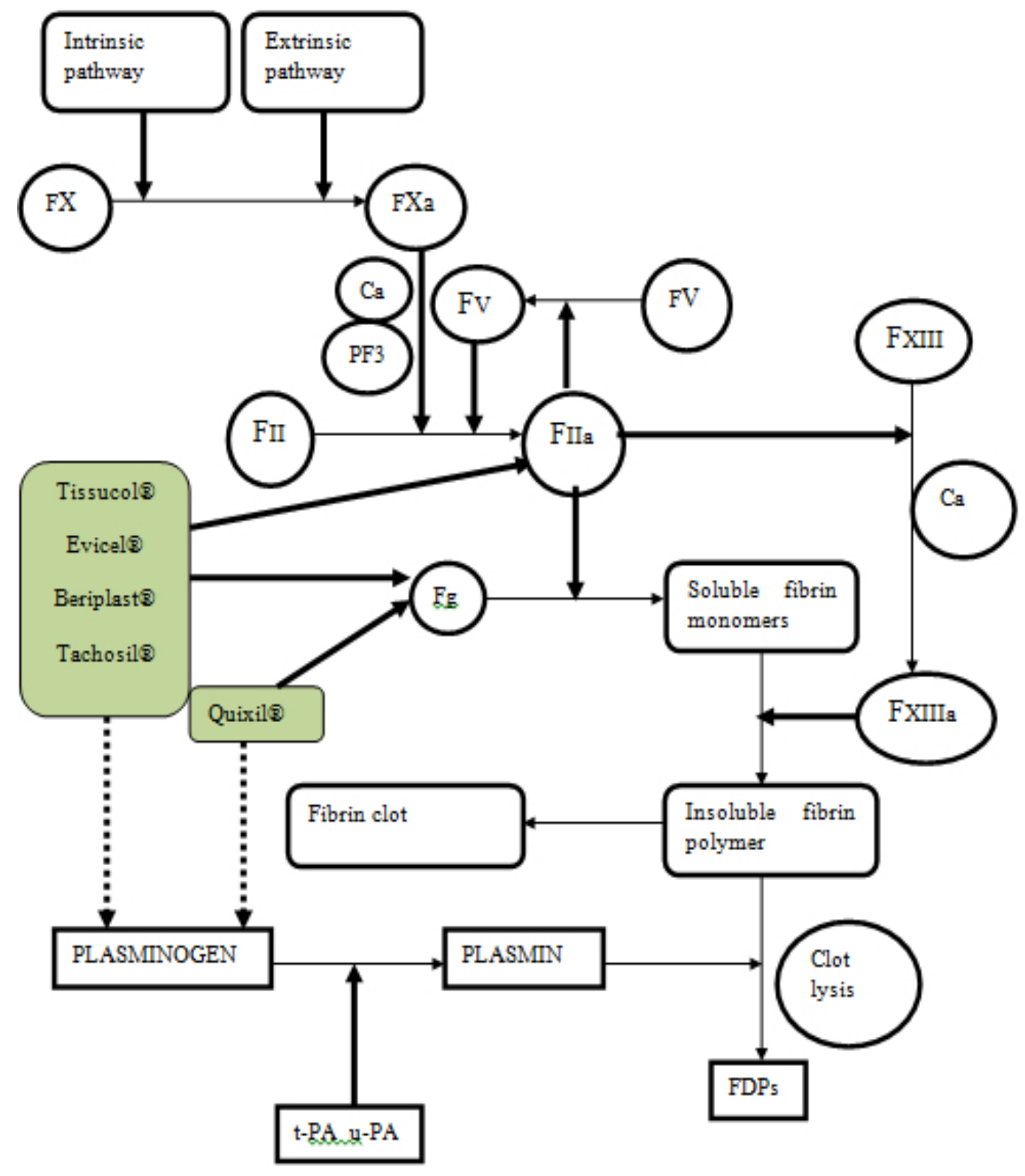

Figure. 1. Coagulation cascad and fibrin glue targets. FX = factor $\mathrm{X} ; \mathrm{FXa}=$ activated factor $\mathrm{X}$; $\mathrm{Ca}=$ ionized calcium; FV = factor V; FVa = activated factor V; FII = thrombin; FIIa = activated thrombin; Fg = fibrinogen; FXIII = factor XIII ; FXIIIa = activated factor XIII; FDPs = fibrin degradation products; t-PA = tissue plasminogen activator; $\mathrm{u}-\mathrm{PA}=$ urokinase plasminogen activator; $\mathrm{PF} 3=$ platelet factor 3 . Full arrows in bold type: activation; Dotted arrows in bold type: inhibition 
Thrombin (dissolved in a calcium chloride solution) converts fibrinogen into fibrin monomers, to form unstable fibrin clots. F XIIIa catalyzes cross-linking between glutamyl and lysyl residues of adjacent fibrin fibers: it crosslinks both the $\gamma$-chains (fast reaction in the presence of low concentration of $\mathrm{F}$ XIII $=0.5$ $\mathrm{U} / \mathrm{mL}$ ) and the $\alpha$-chains (slow reaction in the presence of high concentration of F XIII $=10 \mathrm{U} /$ $\mathrm{mL}$ ) of fibrin. The cross-linking by F XIIIa makes the clot mechanically stable. Polymerization is achieved within two hours. At the same time, F XIII is effective in a variety of ways: acceleration of wound healing promotes migration and proliferation of fibroblasts into the clot, resistance to lysis by plasmin creates covalent bonds between fibrin molecules and $\alpha 2$-antiplasmin. Clot lysis is achieved within two weeks, the time it takes for the anti-fibrinolytic agent to diffuse out of the fibrin clot.

Five products are commercially available in ${\text { France: } \text { Evicel }^{\circledR} \text {, } \text { Quixil }^{\circledR} \text {, Tissucol }}^{\circledR}$, Beriplast ${ }^{\circledR}$ and Tachosil ${ }^{\circledR}$. All of these glues contain thrombin and fibrinogen from pooled plasma, but their final qualitative and quantitative composition differs, so they cannot be considered generic products $(1,9)$.

Thus, commercially available fibrin glues differ in the quantities of F XIII they contain. When the role of this factor in glue efficacy was assessed (2), Beriplast ${ }^{\circledR}$, with the highest F XIII content (40-80 U/mL), showed a rate of complete $\gamma-\gamma$ chains cross-linking within one minute that was significantly higher $(p<0.05)$ than the others. Late hemostasis (seven days after application of the fibrin sealant) was achieved in
$100 \%$ of cases with Beriplast ${ }^{\circledR}$ but in only $27 \%$ of cases using fibrin glue without F XIII $(p<0.01)$. This finding shows that F XIII improves the quality of fibrin glues by i) making fibrin clots more resistant to lysis by plasmin (covalent bond between F XIII and $\alpha 2$-antiplasmin); ii) increasing the tensile strength of the clot up to fivefold; iii) reducing blood loss; iv) decreasing the need for fibrin reapplication (only $20 \%$ compared with $46.7 \%$ for fibrin glues without F XIII); v) reducing postoperative adhesions -correlated with premature clot lysis- to $46.7 \%$ for fibrin sealant containing F XIII, as compared with $80 \%$ for sealant without F XIII $(p<0.06)$.

Anti-fibrinolytic agents (employed to prevent clot lysis before use and to preserve fibrin clots until wound healing) used in fibrin sealants vary: bovine aprotinin (serine protease inhibitor) in Tissucol $^{\circledR}$ and Beriplast ${ }^{\circledR}$, tranexamic acid in Quixil $^{\circledR}$, no anti-fibrinolytic agent in Tachosil ${ }^{\circledR}$. The need to include an anti-fibrinolytic agent in fibrin glues has been debated in the literature (10). Thus, unlike its predecessors TachoComb ${ }^{\circledR}$ (containing bovine aprotinin and bovine thrombin) and TachoComb $\mathrm{H}^{\circledR}$ (containing bovine aprotinin and human thrombin), Tachosil ${ }^{\circledR}$ is free of bovine components. Indeed, aprotinin has been shown not to affect fibrinolysis: the time required for hemostasis when fibrin glue is administered with heparin increases to $75 \%(p=0.005)$ for Tachosil $^{\circledR}$ and to $80 \%$ for TachoComb ${ }^{\circledR}(p=$ 0.001). Furthermore, Tachosil ${ }^{\circledR}$ shows the same hemostatic efficacy as TachoComb $\mathrm{H}^{\circledR}$, even in hyperfibrinolysis conditions (11).

\section{PREPARATION OF FIBRIN GLUES}

\begin{tabular}{|c|c|c|c|c|c|}
\hline & TISSUCOL $^{\circledR}$ & BERIPLAST $^{\circledR}$ & QUIXIL $^{\circledR}$ & TACHOSIL $^{\circledR}$ & EVICEL $^{\circledR}$ \\
\hline Plasma proteins & $100-130 \mathrm{mg} / \mathrm{mL}$ & $65-115 \mathrm{mg} / \mathrm{mL}$ & $60-80 \mathrm{mg} / \mathrm{mL}$ & $\begin{array}{l}\mathrm{NC} \\
\text { (equine collage) }\end{array}$ & $80-120 \mathrm{mg} / \mathrm{mL}$ \\
\hline Fibrinogen & $70-110 \mathrm{mg} / \mathrm{mL}$ & $90 \mathrm{mg} / \mathrm{mL}$ & $40-60 \mathrm{mg} / \mathrm{mL}$ & $5.5 \mathrm{mg} / \mathrm{cm}^{2}$ & $55-85 \mathrm{mg} / \mathrm{mL}$ \\
\hline Thrombin & $500 \mathrm{UI} / \mathrm{mL}$ & $500 \mathrm{UI} / \mathrm{mL}$ & $1000 \mathrm{UI} / \mathrm{mL}$ & $2 \mathrm{UI} / \mathrm{cm}^{2}$ & $800-1200 \mathrm{UI} / \mathrm{mL}$ \\
\hline Factor XIIIa & $10-50 \mathrm{UI} / \mathrm{mL}$ & $40-80 \mathrm{UI} / \mathrm{mL}$ & - & - & $91 \mathrm{UI} / \mathrm{mL}$ \\
\hline Fibronectin & $5.5 \mathrm{mg} / \mathrm{mL}$ & - & $40-60 \mathrm{mg} / \mathrm{mL}$ & - & $\mathrm{NC}$ \\
\hline Plasminogen & $0.08 \mathrm{mg} / \mathrm{mL}$ & - & - & - & - \\
\hline $\begin{array}{l}\text { Anti-fibrinolytic } \\
\text { agent }\end{array}$ & $\begin{array}{l}\text { Bovine } \\
\text { aprotinin } \\
3000 \mathrm{UI} / \mathrm{mL}\end{array}$ & $\begin{array}{l}\text { Bovine aprotinin } \\
1000 \mathrm{UI} / \mathrm{mL}\end{array}$ & $\begin{array}{l}\text { Tranexamic acid } \\
100 \mathrm{mg} / \mathrm{mL}\end{array}$ & - & - \\
\hline
\end{tabular}




\begin{tabular}{|c|c|c|c|c|c|}
\hline & $\begin{array}{l}\text { EVICEL }^{\circledR} \\
\text { (Johnson and } \\
\text { Johnson) }\end{array}$ & $\begin{array}{l}\left.\text { TISSUCOL }^{(}\right) \\
\text {(Baxter) }\end{array}$ & $\begin{array}{l}\text { BERIPLAST }^{(B)} \\
\text { (ZLB Behring) }\end{array}$ & $\begin{array}{l}\text { QUIXIL }^{\circledR} \\
\text { (Johnson and } \\
\text { Johnson) }\end{array}$ & $\begin{array}{l}\text { TACHOSIL }^{\circledR} \\
\text { (Nycomed) }^{\text {Nych }}\end{array}$ \\
\hline \multirow[t]{2}{*}{ Presentation } & $\begin{array}{l}\text { Frozen components } \\
\text { for glue solution } \\
1 / 2 / 5 \mathrm{~mL}\end{array}$ & $\begin{array}{l}\text { Lyophilized } \\
\text { component for } \\
\text { reconstitution } \\
1 / 2 / 5 \mathrm{~mL}\end{array}$ & $\begin{array}{l}\text { Lyophilized } \\
\text { component for } \\
\text { reconstitution } 0.5 / 1 / 3 \\
\text { mL }\end{array}$ & $\begin{array}{l}\text { Frozen } \\
\text { components } \\
\text { for glue } \\
\text { solution } \\
2 / 5 \mathrm{~mL}\end{array}$ & \multirow[t]{2}{*}{$\begin{array}{l}\text { Sponge } \\
23 / 45 \mathrm{~cm}^{2}\end{array}$} \\
\hline & $\begin{array}{l}\text { Triple lumen catheter } \\
\text { drip and spray }\end{array}$ & $\begin{array}{l}\text { Single lumen } \\
\text { catheter with } \\
\text { spray accessory }\end{array}$ & $\begin{array}{l}\text { Single lumen catheter } \\
\text { with spray accessory }\end{array}$ & $\begin{array}{l}\text { Triple lumen } \\
\text { catheter drip } \\
\text { and spray }\end{array}$ & \\
\hline Indications & \multicolumn{2}{|c|}{$\begin{array}{l}\text { Adjunct to hemostasis in surgery when } \\
\text { conventional surgical techniques are } \\
\text { inadequate or impractical }\end{array}$} & $\begin{array}{l}\text { Tissue gluing } \\
\text { Adjunct to hemostasis } \\
\text { surgical techniques are }\end{array}$ & $\begin{array}{l}\text { surgery when } \\
\text { nadequate or in } \\
\quad \text { Liq : } 10\end{array}$ & $\begin{array}{l}\text { onventional } \\
\text { oractical }\end{array}$ \\
\hline Dosage & $\begin{array}{l}\text { Liq : NC } \\
\text { Sp: } 20-100 \mathrm{~cm}^{2}\end{array}$ & $\begin{array}{l}\mathrm{Liq}: 10 \mathrm{~cm}^{2} \\
\mathrm{Sp}: 25-100 \mathrm{~cm}^{2}\end{array}$ & $\begin{array}{l}\text { Liq : NC } \\
\text { Sp: } 50-100 \mathrm{~cm}^{2}\end{array}$ & $\begin{array}{l}\mathrm{cm} \mathrm{cm}^{2} \\
\mathrm{~cm}^{2}\end{array}$ & $\begin{array}{l}23 \mathrm{~cm}^{2} \\
45 \mathrm{~cm}^{2}\end{array}$ \\
\hline Conservation & 2 years $\left(-18^{\circ} \mathrm{C}\right)$ & 2 years $\left(2-8^{\circ} \mathrm{C}\right)$ & 2 years $\left(2-8^{\circ} \mathrm{C}\right)$ & $\begin{array}{l}2 \text { years }(- \\
\left.18^{\circ} \mathrm{C}\right)\end{array}$ & 3 years $\left(25^{\circ} \mathrm{C}\right)$ \\
\hline Stability & $24 \mathrm{~h}\left(25^{\circ} \mathrm{C}\right)$ & $4 \mathrm{~h}\left(25^{\circ} \mathrm{C}\right)$ & $24 \mathrm{~h}\left(25^{\circ} \mathrm{C}\right)$ & $24 \mathrm{~h}\left(25^{\circ} \mathrm{C}\right)$ & 3 years $\left(25^{\circ} \mathrm{C}\right)$ \\
\hline $\begin{array}{l}\text { Stability after } \\
\text { reconstitution }\end{array}$ & 30 days $\left(2-8^{\circ} \mathrm{C}\right)$ & $4 \mathrm{~h}$ & $8-24 h$ & $\begin{array}{l}30 \text { days }(2- \\
\left.8^{\circ} \mathrm{C}\right)\end{array}$ & - \\
\hline Reconstitution & $\begin{array}{l}\text { Thawing } \\
1 \text { day }\left(2-8^{\circ} \mathrm{C}\right) \\
1 \mathrm{~h}\left(20-25^{\circ} \mathrm{C}\right) \\
10 \text { min }\left(37^{\circ} \mathrm{C}\right) \\
\text { Draw into applicator }\end{array}$ & $\begin{array}{l}\text { Reconstitute } \\
\text { Warm } \\
40 \mathrm{~min}\left(37^{\circ} \mathrm{C}\right) \\
\text { Draw into } \\
\text { applicator }\end{array}$ & $\begin{array}{l}\text { Reconstitute } \\
\text { Warm } \\
15 \text { min }\left(37^{\circ} \mathrm{C}\right) \\
\text { Draw into applicator }\end{array}$ & $\begin{array}{l}\text { Thawing } \\
\text { Draw into } \\
\text { applicator }\end{array}$ & Ready for use \\
\hline Resorption & - & 2 weeks & 2 weeks & 2 weeks & 24 weeks \\
\hline Status & PDPs: traceability and & pharmacovigilance & & & \\
\hline
\end{tabular}

Table 2 summarizes features of the fibrin glues commercially available. However, these features can differ from country to country for the same product (12). Quixil ${ }^{\circledR}$ is very handy and easy to use: it is quickly prepared (5-7 min) and does not require warming, so Quixil ${ }^{\circledR}$ is very useful when it is decided at the very last moment to apply fibrin glue. In addition, this product can be stored for one month at $2-8^{\circ} \mathrm{C}$ if there is a cold chain break. Quixil $^{\circledR}$ possesses a triple lumen catheter which makes it handier than other fibrin glues: the fibrin component and the thrombin component remain separate right up to the tip of the catheter, only meeting on the wound. This precludes clots forming in the catheter, so fibrin glue loss is reduced. Finally, this product enables surgeons to switch between spraying and dripping without changing devices (9). However, there is one main drawback to Quixil ${ }^{\circledR}$ : it remains transparent before and after coagulation. There is no visible change, therefore, to confirm that the glue is acting (unlike other fibrin glues that become opaque after coagulation), although the transparency makes it possible to preserve the visibility of underlying tissues.

Fibrin sealant may be denatured after exposure to solutions containing ethanol, iodine or heavy metals. For this reason, the European Medicines Evaluation Agency (EMEA) recommends in The Guideline on The Clinical Investigation of Plasma Derived Fibrin Sealant/Haemostatic Products that the use of these antiseptic solutions before applying the glue be avoided (13).

\section{Fibrin sealant manufacture}

Methods of manufacturing fibrin glues differ: Schwartz method for Tissucol ${ }^{\circledR}$ and Beriplast ${ }^{\circledR}$ 
(production of purified fibrinogen), Martinowitz method for Quixil ${ }^{\circledR}$ (production of biologically active cross-linked fibrinogen-fibronectin multimers). Fibrinogen-fibronectin multimers enable the fibrin clot to increase its strength when binding to collagen, thus enhancing adhesion of the clot to the extracellular matrix (14).

The fibrinogen concentrate is obtained by centrifugation from whole blood, followed by cryoprecipitation or chemical precipitation with ethanol, polyethylene glycol (PEG) or ammonium sulfate.

Cryoprecipitation is the most common method of making fibrin glue and involves several freeze-thaw cycles: freezing blood between $-20^{\circ} \mathrm{C}$ and $-80^{\circ} \mathrm{C}$ for $1-24$ hours and then thawing blood at $4^{\circ} \mathrm{C}$ for 12 hours. Fibrinogen is then removed by centrifugation of plasma. The quantity of fibrinogen obtained ranges from 20 to $40 \mathrm{mg} / \mathrm{mL}$; however, this method involves numerous variables (freezing and thawing conditions, number of freeze-thaw cycles), which impedes reproducibility.

Chemical methods are faster (single precipitation step) and yield higher quantities of fibrinogen $(30-50 \mathrm{mg} / \mathrm{mL})$, but the purity of the product is an issue (15). Using ethanol extraction leads to premature clotting of the fibrinogen due to the high concentration of alcohol in the end product; ethanol also decreases F XIII activity, which reduces the tensile strength of the clot (16, 17). Ammonium sulfate precipitation increases the concentration of albumin in the glue, which can interfere with clotting (18); but this ammonium sulfate can precipitate a higher quantity of fibrinogen, leading to higher tensile strength $\left(41 \mathrm{~g} / \mathrm{cm}^{2} \quad 10 \mathrm{~min}\right.$ after thrombin addition). Using PEG to harvest fibrinogen requires numerous steps and makes the glue less clottable (19). Ethanol and PEG are therefore less efficient than ammonium sulfate for harvesting fibrinogen, giving ammonium sulfate the edge over other chemical methods (20).

The thrombin component is manufactured separately from the fibrinogen component: a pre- purified human prothrombin is activated into thrombin and then undergoes purification by chromatography (21).

Plasma-derived products are potential virustransmitters. To ensure viral safety, therefore, certain measures need to be taken with respect to this residual risk when manufacturing fibrin glues. First, blood donors are carefully selected. Then, all blood donations are screened for HIV-1, HIV2, HBV, HCV and parvovirus B19. Finally, to decrease the risk of prion transmission, bovine aprotinin has been replaced by tranexamic acid in Quixil $^{\circledR}(9)$.

EMEA recommends that plasma-derived products undergo two complementary validated processes for virus inactivation/removal, to increase efficacy against unknown viral pathogens. One of these inactivation steps should be effective even against non-enveloped viruses. Quixil $^{\circledR}$ undergoes two different methods of viral inactivation, and thus meets the EMEA guidelines. However, with both Tissucol ${ }^{\circledR}$ and Beriplast $^{\circledR}$ the two steps of viral inactivation are identical instead of complementary in their mode of action, and therefore these products do not meet the EMEA guidelines. Nevertheless, the risk of virus transmission for Tissucol ${ }^{\mathbb{B}}$ and Beriplast ${ }^{\mathbb{B}}$ is assessed as low, with a good margin of safety. From 1991 to 2000 (Behring data from postlaunch period), 5.6 million doses of Beriplast ${ }^{\mathbb{B}}$ were applied and no cases of HIV or HBV transmission were registered (2).

The safety of plasma-derived products with respect to HIV, HBV and $\mathrm{HCV}$ is now well established, even when a single mode of virus inactivation is used. On the other hand, several reported cases of parvovirus B19 transmission have been linked to coagulation factors or fibrin sealant (22, 23). NAT (Nucleic acid Amplification Testing), a new screening method to eliminate viruses, limits the amount of parvovirus B19 to below $10^{5} \mathrm{geq} / \mathrm{mL}$, but risk of infection remains.

\begin{tabular}{lcc}
\hline \multicolumn{2}{c}{ Table 3. Viral inactivation/removal methods } & \\
\hline & Fibrinogen & Thrombin \\
\hline & Solvent detergent treatment $(1 \%$ TnBP, $1 \%$ & Solvent detergent treatment $(1 \%$ \\
QUIXIL $^{\circledR}$ & Triton X-100) for $4 \mathrm{~h}$ at $30^{\circ} \mathrm{C}$ & TnBP, $1 \%$ Triton X-100) for $6 \mathrm{~h}$ at \\
EVICEL $^{\circledR}$ & Pasteurization for $10 \mathrm{~h}$ at $60^{\circ} \mathrm{C}$ & $26^{\circ} \mathrm{C}$ \\
& Nanofiltration $(28 \mu)$ \\
TISSUCOL $^{\circledR}$ & Two-step vapor heating at $60^{\circ} \mathrm{C}$ and $80^{\circ} \mathrm{C}$ & \\
BERIPLAST $^{\circledR}$ & 2 pasteurizations & \\
\hline
\end{tabular}




\section{ASSAYS PERFORMED}

\begin{tabular}{llll}
\hline \multicolumn{2}{l}{ Table 4. Comparison of fibrin glue efficacy } & & \\
\hline & \multirow{2}{*}{ Adhesive strength in vitro } & \multicolumn{2}{l}{ Efficacy in vivo (hemostasis) } \\
& & Early & Late \\
\hline BERIPLAST $^{\circledR}$ & +++ & +++ & +++ \\
TISSUCOL $^{\circledR}$ & + & +++ & +++ \\
QUIXIL $^{\circledR}$ & +++ & + & + \\
\hline
\end{tabular}

Criteria to be met in fibrin glues include achieving fast hemostasis, high clot strength and elasticity and good clot adhesion to the wound (9).

Fibrin sealants are used as hemostatic agents in several fields of surgery, including cardiovascular surgery (24-26), urology (27), otolaryngology $(28,29)$, neurosurgery (30-33), orthopedic surgery $(34,35)$, gastro-intestinal surgery (although benefits are not well established) (36-38), thoracic surgery (39-41) (for air leak sealing). For tissue gluing and tissue attachment, fibrin glues are not an adequate substitute for sutures, as their mechanical strength is low (42). Tissucol ${ }^{\circledR}$ and Beriplast ${ }^{\circledR}$ have been shown to achieve hemostasis in $100 \%$ of cases after the first application, whereas hemostasis is achieved in $30 \%$ of cases with Quixil ${ }^{\circledR}$ (1).

Retrospective monocentric studies are usually undertaken on small cohorts and present a varying standard of evidence (low for Beriplast ${ }^{\circledR}$, good for Tissucol $^{\circledR}$ ). To date, there have been no comparative trials involving all commercially available fibrin glues (43).

\section{Quixil $^{\circledR}$}

Because of its low F XIII activity $(<1 \mathrm{UI} / \mathrm{mL})$ and fibrinogen content, Quixil ${ }^{\circledR}$ presents a significantly greater elongation $(p<0.008)$ compared with Beriplast $^{\circledR}$ and Tissucol ${ }^{\circledR}$. Moreover, the higher concentration of thrombin in Quixil $^{\circledR}$ can contribute to rapid hemostasis. However, Quixil $^{\circledR}$ does not possess good hemostatic properties, consequently requiring application in greater volume $(1.75 \mathrm{~mL}+/-0.39 \mathrm{~mL}$ versus $1.2 \mathrm{~mL}+/$ $0.00 \mathrm{~mL}$ with Beriplast $\left.{ }^{\circledR}\right)$ to obtain similar results. In animal models, a second application was required in $70 \%$ of animals $(p<0.05)$, whereas complete hemostasis was rapidly achieved in $100 \%$ of animals after the first Beriplast $^{\circledR}$ spraying (1). Moreover, a zero rate of late hemostasis was found with Quixil ${ }^{\circledR}$, as opposed to $100 \%$ with Beriplast $^{\circledR}(p<0.05)$. Generally, fibrin glues with poor F XIII activity lead to weak fibrin clots and are associated with premature clot lysis, thus putting the patient at higher risk of hemorrhage. In addition, the fibrin clot obtained with Quixil ${ }^{\circledR}$ disintegrated within one week, exposing fragile tissue in its granulation phase (1).

Another study carried out with animal models assessed time to hemostasis and blood loss: Quixil $^{\circledR}$ reduced time to hemostasis and blood loss, as well as requiring less volume than the other fibrin sealants. Indeed, blood loss was measured at $372 \mathrm{~mL}$ and lasted 372 seconds without any fibrin glue; after applying Quixil ${ }^{\circledR}$ blood loss was less than $1 \mathrm{~mL}$ and lasted only 25 seconds (44).

Basically, clinical trials have focused on orthopedic and hepatic surgery, although Quixil ${ }^{\circledR}$ is licensed for all types of surgery except neurosurgery (44). Thus, Quixil ${ }^{\circledR}$ was tested in orthopedic surgery (45) and revealed blood loss reduction 12 hours post-surgery $(184.5+/-28.9$ $\mathrm{mL}$ versus $408.3+/-54.6 \mathrm{~mL}$ in control group, $p$ $=0.002$ ).

Finally, one study found that Quixil $^{\circledR}$ decreases time to hemostasis in vascular surgery (2.5 min versus $17 \mathrm{~min}$ in control group, $p=$ $0.001)(46)$.

\section{Tissucol $^{\circledast}$}

The tensile strength obtained with Tissucol ${ }^{\circledR}$ is significantly lower than with other fibrin glues (0.008-0.012 $\mathrm{N}$ versus $0.24-0.37 \mathrm{~N}, p<0.006$ ) (1). However, Tissucol ${ }^{\circledR}$ scores well on early and late hemostasis (100\%) and allows a more homogenous application of the fibrin glue layer than Beriplast ${ }^{\mathbb{R}}$.

Several studies involving Tissucol ${ }^{\circledR}$ in numerous fields of surgery (hepatic, urological, gynecological, thoracic, vascular, ENT, neurological) have been performed.

A clinical trial assessed Tissucol ${ }^{\circledR}$ efficacy in cardiopulmonary surgery and found the fibrin 
glue to be more effective than conventional surgical patient care in achieving fast hemostasis. Indeed, Tissucol ${ }^{\circledR}$ was used with $92.6 \%$ success to seal a bleeding wound within 5 min, versus $12.4 \%$ success using conventional methods $(p<0.001)$. Furthermore, the fibrin glue used as second treatment allowed bleeding control in $82.0 \%$ of cases, and postoperative blood loss was significantly lower in the fibrin sealant group $(p<$ 0.05) (47).

In six laparoscopic spleen-preserving procedures, Tissucol ${ }^{\circledR}$ eliminated both the need for laparotomy and postoperative bleeding (48).

Similarly, in the treatment of primitive and secondary abdominal relapsed fistulas, Tissucol ${ }^{\circledR}$ registered a high success rate and acted rapidly (49).

\section{Beriplast $^{\circledast}$}

Few of the clinical studies available specifically consider Beriplast, most being based on data for Tissucol, whose composition is similar (43).

Beriplast $^{\circledR}$ is recognized for use in several types of surgery as an effective hemostatic agent (neurosurgery, aerostasis) (50). As the end of bleeding is correlated with immediate hemostasis, the best results were found with Beriplast ${ }^{\circledR}$ : in a comparative study, optimum F XIII activity was reported to be about $60 \mathrm{UI} / \mathrm{mL}$ or more, in order to obtain the fastest hemostasis. Beriplast ${ }^{\circledR}$ achieved the best early hemostasis (clotting obtained in $100 \%$ of cases after first application) and the lowest blood loss (1).

However, this study highlighted the need for large quantities of fibrin to enhance wound healing. It should be noted that excessive fibrin concentration prevents neutrophils from migrating into the clot, an important step in wound healing. In the same way, excessive thrombin activity ( $>$ $1000 \mathrm{UI} / \mathrm{mL}$ ) could activate intravascular clotting. It is therefore essential to apply wellhomogenized fibrin glue in a thin layer on the wound.

\section{Tachosil $^{\circledR}$}

Fifteen years of experience with TachoComb ${ }^{\circledR}$ can be exploited in Europe. Assays were mainly undertaken in hepatic surgery, but Tachosil ${ }^{\circledR}$ is licensed for all branches of surgery. Indeed, Tachosil $^{\circledR}$ is effective in multiple indications, as shown by randomized controlled trials concerning hepatic surgery, thoracic surgery and urology (51). Moreover this product is very cost-effective compared with other fibrin sealants.

\section{Evicel $^{\circledR}$}

A comparative study of Evicel ${ }^{\circledR}$ versus Tisseel ${ }^{\circledR}$ was carried out with regard to mechanical, kinetic and biochemical properties. Evicel $^{\circledR}$ led to significantly higher tensile strength of the fibrin clot than Tisseel ${ }^{\circledR}(p<0.05)$, within a shorter period of time, and presented greater resilience to stretching. These results were attributed to the higher F XIII content in Evicel $^{\circledR}$ compared with Tisseel $^{\circledR}(52)$. When Evicel $^{\circledR}$ was assessed in vascular surgery, it reduced the time to hemostasis, allowing hemostasis to be achieved within four min in $85 \%$ of patients versus $39 \%$ of patients using manual compression $(p<0.001)$ (53). Evicel ${ }^{\circledR}$ was also tested in rhinoplasty: bruising and swelling significantly decreased after its application on a lateral osteotomy site on postoperative days 1, 7 and 21 (54).

\section{Methods of application}

Fibrin glue can be applied in two different ways: dripping and spraying. However, spraying leads to better hemostasis than dripping, as well as to lower blood loss: only $7 \mathrm{~mL}+/-16 \mathrm{~mL}$ with spraying versus $110+/-160 \mathrm{~mL}$ with dripping. The new rub-and-spray application method was assessed for the treatment of acute aorta dissection (high-risk surgery due to systematic heparinization and hypothermic cardiopulmonary bypass) and obtained the most effective hemostasis with the strongest sealing and the lowest postoperative blood loss. Using this method, a fibrinogen solution is first rubbed on the wound and then fibrinogen and thrombin solutions are simultaneously sprayed on (55).

\section{Salmon fibrin glue}

Fibrin glue prepared from the blood of farmed Atlantic salmon was assessed and found to significantly decrease the risk of infection by viruses, bacteria or prions compared with fibrin glue prepared with human or bovine proteins. This strong barrier to trans-species infections is due to the much lower ambient temperature and the remote phylogeny of salmon. The study reported similar structures and properties for fibrinogen and thrombin from salmon and from human fibrin clots; the mechanism of the clotting cascade is also similar to that in mammals. Moreover, salmon fibrin sealant achieved greater hemostasis, forming clots insensitive to changes in $\mathrm{pH}$ and ionic strength. No immune reactivity was developed with salmon glues (56). 


\section{Scaffold for drug delivery system and tissue engineering}

\section{Drug delivery system}

Fibrin glues have been investigated as drug delivery systems. As they undergo slow lysis, they can be used as a scaffold for several molecules.

Growth factors

Fibrin sealant can be used as a binding reservoir for growth factors VEGF (Vascular Endothelial Growth Factor), TGF- $\beta 1$ (Transforming Growth Factor), IGF (Insulin Growth Factor) and bFGF (basic Fibroblastic Growth Factor) (57-60). The kinetics of the release of these growth factors from fibrin glue may increase vascularization of subcutaneous tissues. In a study, interaction between TGF- $\beta 1$ and fibrin was observed: indeed, TGF- $\beta 1$ release from the gel decreased with increasing fibrinogen content. After being released from platelets, TGF- $\beta 1$ appears to be temporarily stored in the fibrin clot, thus prolonging TGF- $\beta 1$ activity in the target zone. Thus, several assays show improved tissue engineering using fibrin glue as a scaffold for growth factor release (61-64).

bFGF can induce the migration and proliferation of endothelial cells (enhanced angiogenesis) and smooth muscle cells (myocardial tissue repair). Application of fibrin glue containing this growth factor to transmyocardial tissue in order to improve angiogenesis and cardiac perfusion was assessed in animal models. Direct injection of bFGF into transmyocardial tissue increased total vascular density by $40 \%$, but a two-fold increase in the number of large vessels was observed. Hence bFGF alone appears to increase vessel size but not the total number of vessels. When administered via fibrin glue, bFGF increases total vascular density by $28 \%$, with a $59 \%$ increase in the number of large vessels; consequently, fibrin sealant containing bFGF could induce arteriogenesis (63).

\section{Anesthetic drugs}

Fibrin glues containing lidocaine were administered in order to reduce postoperative pain. After breast augmentation, fibrin glue containing lidocaine was injected into the subpectoral pocket: postoperative pain was significantly lower $(p<0.05)$ compared with patients receiving lidocaine or fibrin glue alone $(65,66)$. Similarly, fibrin glue containing lidocaine was applied on the tonsillar fossae after tonsillectomy to evaluate its analgesic effects: time to normal eating was shortened to 2.83 days (versus 3.178 days for patients receiving regular fibrin glue) and time of analgesic administration was decreased to 2.88 days (4.91 days for patients receiving regular fibrin glue) (67).

\section{Antibiotics}

Fibrin sealants have also been used as a drug delivery system for antibiotics. In a study, vancomycin was incorporated into the fibrinogen component and applied to vascular Dacron grafts in rats. Local vancomycin concentration in the target area was found higher using fibrin glue as a carrier, compared with intravenous injection of vancomycin $(89.58 \mu \mathrm{h} / \mathrm{g}$ with a targeting index of 12.11 versus $7.40 \mu . \mathrm{h} / \mathrm{g}$ ). S. aureus was injected into Dacron grafts on rats: none of the six grafts treated with fibrin glue containing vancomycin became infected, whereas two out of the six grafts treated by vancomycin IV injection became infected (68).

A case report on a patient suffering from acute endocarditis revealed the efficacy of vancomycin incorporated into Beriplast ${ }^{\circledR}(0.5 \mathrm{~g}$ of vancomycin $/ 3 \mathrm{ml}$ of fibrin glue) in vascular graft surgery (patch composed of Dacron graft and pericardium using fibrin glue containing vancomycin): 11 months after the surgery no prosthetic valve endocarditis had been reported (69).

Other antibiotics were tested with fibrin glue: a concentration of $400 \mu \mathrm{g}$ of teicoplanin, cephalothin or gentamicin was incorporated into 1 $\mathrm{g}$ of fibrin glue and then added to a $500 \mathrm{IU} / \mathrm{ml}$ thrombin solution. Antibiotics were released within 96 hours, thereby initiating antibacterial activity during this time, which suggests that this delivery system offers prevention and treatment benefits in ocular surgery (70).

Chemotherapeutic agents

Treatment of patients suffering from cancer by fibrin glues containing chemotherapeutic agents led to increased agent concentration in tumors and reduction of adverse effects.

First, an in vitro study assessed the local drug delivery of doxorubicin from Beriplast $^{\circledR}$ (71). Three groups were treated with doxorubicin: doxorubicin with solution, doxorubicin incorporated in fibrin glue and doxorubicin incorporated in fibrin glue containing sodium alginate. In vitro release of this anti-cancer molecule was found to take respectively $3.7 \mathrm{~h}, 8.7$ 
$\mathrm{h}$ and $81 \mathrm{~h}$. Since prolonged release of doxorubicin was better with fibrin glue containing sodium alginate, an in vivo study was undertaken on an AH60C tumor in the rat back. Fibrin glue containing $6 \mathrm{mg}$ of doxorubicin and $2.5 \mathrm{mg}$ of alginate sodium was applied, resulting in an extremely high concentration of doxorubicin in the tumor extracellular fluid (concentration inversely correlated with tumor volume, $\mathrm{r}=$ 0.882), while the plasma concentration remained low.

Second, a study compared the release properties of several anti-cancer drugs from an autologous fibrin glue both containing and not containing aprotinin (72). Fluorouracil, Tegafur and Mitomycin $\mathrm{C}$ mixed with fibrin glue (with or without aprotinin) were quickly released (steady state level after 1-2 hours), suggesting the lack of interaction between these molecules and autologous fibrin glue. However, when Etoposid and Doxorubicin were mixed with fibrin glue containing aprotinin, their concentration gradually increased, peaked after 24 hours, then gradually decreased. Thus this study proves that aprotinin can be valuable in controlling the speed of fibrin glue lysis. The findings of this study show that the release properties of anti-cancer drugs differ according to hydrophobicity: they need to be lipophilic to achieve sustained release from fibrin glue.

\section{Stem cells}

Mesenchymal stem cells (MSC) from bone marrow can be mixed with fibrin glues in order to regenerate or repair tissues (especially bone tissue). Fibrin glue is a suitable vehicle for mesenchymal stem cell transplantation: it promotes angiogenesis and its F XIII content enhances the migration and proliferation of stem cells (73).

\section{Platelet-rich fibrin (PRF)}

PRF is extracted by centrifugation from whole blood without anticoagulants, thus creating a clot in the middle of the tube containing principally fibrin, platelets and leukocytes. PRF can be used directly as a healing biomaterial; alternatively, it can be used as a biological connector between grafted elements (after being cut and mixed with grafts) and will induce neo-angiogenesis in the graft. Biological membranes can be produced from PRF after withdrawing and compressing the serum with a piston (tympanoplasty).

In chondrogenesis, PRF is also a biological scaffold which has been tested as an MSC carrier: $\alpha$-granules contained in platelets release growth factors (TGF- $\beta 1$ and IGF-1) that enhance cartilage regeneration. A clinical trial was carried out on five patients suffering from cartilage lesion of the femoral condyle: bone marrow was extracted from the iliac crest, then isolated nucleated cells were cultured in fetal bovine serum and mixed with PRF. After curettage of the sclerotic bone, the mixture of MSC-PRF was applied on the injured area. This technique resulted in major improvement in symptoms and knee function within 6-12 months $(p<0.05)$ for all the patients, all of whom were able to regain their normal sports fitness level within 9 months (64). However, this study included only five young patients $(<37$ years old), which may influence outcomes, since cartilage repair mainly depends on the metabolic activity of cells and thus is age-dependent.

The potential of PRF as a carrier for adipocyte grafts in facial lipostructure was evaluated via the stimulation of proliferation of pre-adipocyte cells by a fibrin matrix and the stimulation of adipocyte graft healing by platelet cytokines (74). All 32 patients treated by this technique were satisfied with the end result and no additional adipocyte graft was needed. Indeed, there was no notable resorption even with an HIV-seropositive patient; however, it is difficult to evaluate this criterion without comparative preand postoperative magnetic resonance imaging (MRI). Moreover, there was no control group treated without PRF, which makes results difficult to interpret. In conventional facial lipostructure, major edema persists in $10 \%$ of patients and major bruises in $6 \%$ of patients after 3 and 4 weeks respectively (75), whereas the study reported no cases of edema or bruises. Indeed, angiogenesis is enhanced by grafts containing PRF due to increased vascular and lymphatic drainage, with consequently lower risks of edema or bruises.

In case of stress urinary incontinence, fibrin glue containing muscle-derived stem cells (MDSC) is able to promote urethral sphincter restoration. Fibrin can induce angiogenesis, promote cell attachment and proliferation. Transplantation of fibrin sealant mixed with MDSC resulted in improvement of the stem cells' life-span $(p<0.05)$, increased thickness of urethral muscle and higher microvessel density ( $p$ $<0.01$ ), compared with a group receiving MDSC alone. This suggests that fibrin glue may enhance the differentiation of MDSC towards that of welldifferentiated muscle cells (76). 


\section{Hemostasis and tissue adhesive}

Fibrin glue has the advantage of reducing time to hemostasis in vascular surgery compared with conventional manual compression (77).

In the surgical treatment of inguinal repair by Lichtenstein technique (with sutures), complications frequently reported are chronic pain and high recurrence rate. The use of fibrin glue as a substitute for the previous technique led to similar outcomes with regard to mean operation time, mean length of postoperative hospitalization and mean time to return to work. However, postoperative incidence of chronic pain, inflammation and hematoma were lower when using fibrin glue $(p<0.001)$ (78-81). Indeed, several months after surgery, none of the patients treated with fibrin glue had developed a recurrence and $80 \%$ reported complete absence of chronic pain $(p<0.05)(79,81)$.

Fibrin sealants have been assessed in the treatment of acute ruptures of the Achilles tendon: all patients thus treated were reported cured within five months. In the long term, no pain, no re-rupture and no loss of strength of the Achilles tendon was observed (34).

Fibrin sealants have also proved valuable in obstetrical gynecology. The iatrogenic preterm premature rupture of the fetal membrane (iPPROM) can be due to invasive diagnosis (fetoscopy or amniocentesis). A comparative study was undertaken involving Tissucol ${ }^{\circledR}$ versus five synthetic biocompatible glues for the treatment of iPPROM. It was observed that only Tissucol $^{\circledR}$ and cPEG (catechol-functionalized poly(ethylene glycol)) were able to achieve a strong bonding to fetal membrane (showing a continuous layer between glue and fetal tissue) and were demonstrated to have no in vitro toxicity after 24 hours. Consequently, both can be considered to repair fetal membranes without being toxic for the fetus (82). Puncture of the fetal membrane can also result in a decrease of its tensile strength, which application of fibrin glue can restore; moreover, it may improve the structural and functional integrity of ruptured membrane (83).

Finally, the treatment of anal fistula by injection of fibrin glue can eradicate the risk of fecal incontinence observed in treatment by fistulotomy (84). However, fibrin sealants are ineffective in the treatment of complex anal fistula: only $10 \%$ of patients were cured after 12 months (85), although fibrin glues proved very effective in treating patients suffering from Crohn's disease (86). For the management of duodenal perforation in rats, assays revealed that fibrin glues were no more effective than the conventional suture technique (87).

\section{Fibrin glue toxicity \\ Bovine aprotinin hypersensitivity}

It has been shown that aprotinin does not improve the hemostasis performance of fibrin glue (88). The study compared Tisseel ${ }^{\circledR}$ to a fibrin glue not containing an anti-fibrinolytic agent, and observed a reduction in early hemostasis, higher blood loss and lower survival for Tisseel ${ }^{\circledR}$. Blood loss in the group receiving fibrin glue without an anti-fibrinolytic agent was $1.9+/-1.9 \mathrm{~mL}$ and survival rate was $75 \%(6 / 8)$, while in the group receiving Tisseel $^{\circledR}$, mean blood loss was $30+/$ $6.0 \mathrm{~mL}$ and survival rate was $43 \%(3 / 7)(p<$ 0.01 ). Thus, the legitimacy of adding an antifibrinolytic agent to fibrin can be questioned, particularly since aprotinin can cause hypersensitivity reactions. Indeed, bovine aprotinin contained in fibrin glue is responsible for the production of anti-bovine Factor $\mathrm{V}$ antibodies that may cross-react with Human Factor $\mathrm{V}$ and could lead to severe bleeding. Bovine thrombin contained in fibrin glues led to maximum hypersensitivity reactions due to the production of anti-bovine Factor $\mathrm{V}$ antibodies, which led to its being withdrawn from the French market and replaced by human thrombin (89-93). Aprotinin is a highly immunogenic protein containing 58 amino acids and has an inhibitory activity on serine protease and other woundhealing proteases. Since 1960, 125 anaphylactic reactions after intravenous and local application of fibrin glue have been reported $(94,95)$. However hypersensitivity to aprotinin remains relatively rare: incidence is about $0.5 / 100,000$ applications, but since $90 \%$ of incidents are not declared, an incidence of 5/100,000 applications can be hypothesized (9). Anaphylactic reaction starts within $30 \mathrm{~min}$ after application of the fibrin glue and symptoms reported vary: skin symptoms, mild fever and cardiorespiratory arrest. $40 \%$ are moderate reactions, $50 \%$ are life-threatening and $10 \%$ are lethal (94). These reactions involve antiaprotinin $\operatorname{IgE}$ and $\operatorname{IgG}$ (antibodies remain in $80 \%$ of patients 3.5 months after exposure and persist up to one year) with high histamine rates (96). Generally, repeated use of fibrin sealants containing aprotinin should be avoided.

A case of hypersensitivity reaction several days after application of Beriplast $^{\circledR}$ for the treatment of an aneurysm has been reported, manifested by aphasia and mild right hemiparesis. 
Subsequent MRI revealed neurological deterioration, possibly due to inflammatory reaction. Full resolution of the symptoms without neurological scars occurred a few hours after administration of systemic steroids. Nine months later, a lymphocyte stimulation test was carried out on the patient's serum and revealed hypersensitivity to the fibrinogen/aprotinin/F XIII mixture (97).

\section{Tranexamic acid and neurotoxicity}

Choosing a fibrin glue without aprotinin (Quixil ${ }^{\circledR}$ ) decreases the hypersensitivity risk. However, its tranexamic acid content can lead to neurotoxicity (edema, seizures), making Quixil $^{\circledR}$ contraindicated in neurosurgery or in surgery at high risk of contact with cerebrospinal fluid or dura mater. Tranexamic acid is a specific plasminogen inhibitor able to induce immunogenic reactions (type IV hypersensitivity) (9). Like aprotinin, tranexamic acid is controversial. A recent study, for instance, finds that tranexamic acid is less effective than aprotinin: it significantly decreases the tensile strength of the clot to $40 \%$, as well as the crosslinking of fibrin polymers; consequently, the life span of the clot is reduced (98).

With respect to anti-fibrinolytic agents, a limited number of studies have been carried out and outcomes should be seen in relative terms: indeed, a previous study observed a greater efficacy of tranexamic acid (compared to aprotinin) concerning early hemostasis (improvement in clot percentage: $70.13+/-2.02 \%$ for tranexamic acid versus $61.22+/-2.21 \%$ for aprotinin and $61.28+/-2.36 \%$ for control, $p<$ 0.05) (99).

\section{Other adverse effects}

Thromboembolic complications and disseminated intravascular coagulation (DIVC) can occur if sealant is unintentionally administered intravascularly. Application of fibrin glue must be discontinued immediately if there are signs of hypersensitivity reactions and symptomatic treatment of anaphylactic shock initiated.

Injection of Tissucol ${ }^{\circledR}$ and Beriplast ${ }^{\circledR}$ in nasal mucosa is contraindicated because of the risk of anaphylaxis (13). Several cases of air embolism by spraying at high pressure $(>2.5$ bar) or by spraying at short distances $(<10 \mathrm{~cm})$ have been reported.

The safety of fibrin glue application in nervous tissue has been assessed: a strong and intensive inflammatory reaction was noticed seven days after application, however spontaneous healing occurred without any residual scar tissue. In the long term, fibrin sealants do not induce nerve damage in cerebral tissue, unless they contain tranexamic acid (100).

\section{AUTOLOGOUS FIBRIN SEALANT}

Vivostat $^{\circledR}$ and CryoSeal ${ }^{\circledR}$ are available in the USA and are attracting growing interest in Europe (CE label since 2000). Unlike conventional fibrin sealant products, this kind of fibrin glue is not a plasma-derived product - it is a medical device.

\section{Manufacture}

The automated system allows 4-6 $\mathrm{mL}$ of fibrin to be extracted from $120 \mathrm{~mL}$ of whole blood.

Cryoprecipitation is the method most often employed for a maximum yield of fibrinogen for fibrin sealant manufacturing (CryoSeal ${ }^{\circledR}$ system). In this computer-controlled method, whole blood is centrifuged to harvest a poor-platelet fibrin component. Then the sample undergoes freezing at $-70^{\circ} \mathrm{C}$ followed by thawing at $37^{\circ} \mathrm{C}$; a second freeze-thaw cycle is carried out at $-70^{\circ} \mathrm{C} /+4^{\circ} \mathrm{C}$. Finally, the fibrinogen component is activated by the addition of calcium chloride. This automated system leads to fibrinogen precipitation at a rate of $20 \mathrm{mg} / \mathrm{mL}$ in 1 hour (11).

The Vivostat ${ }^{\circledR}$ system is another device which produces fibrin glue by chemical methods. The fibrinogen component is cleaved by batroxobin (a snake venom protease) to release an acid-soluble fibrin 1 monomer and $\mathrm{FpA}(\mathrm{pH}=4.5)$. Then the solution is mixed with a $\mathrm{pH} 10$ buffer: the resulting neutral solution is free from thrombin and contains calcium. When fibrin 1 and prothrombin solutions are blended, prothrombin is activated into thrombin, which catalyzes the release of fibrin 2 monomer and $\mathrm{FpB}$ from fibrin 1 monomer. Thrombin also activates $\mathrm{F}$ XIII, which cross-links soluble fibrin 2 monomer to form a stable insoluble fibrin 2 polymer. Vivostat $^{\circledR}$ harvests fibrin at a rate of $20 \mathrm{mg} / \mathrm{mL}$ within 1 hour $(101,102)$. This mode of preparation differs from those of Tissucol ${ }^{\circledR}$ and Beriplast $^{\circledR}$, in which both $\mathrm{FpA}$ and $\mathrm{FpB}$ are simultaneously cleaved in order to form a stable fibrin clot; Vivostat ${ }^{\circledR}$ produces a fibrin clot by modifying the $\mathrm{pH}$ of the solution. When the crosslinking kinetics of the different sealants was assessed, the kinetics of Vivostat ${ }^{\circledR}$ was 6- to 20fold higher than those of Tissucol ${ }^{\circledR}$ and Beriplast ${ }^{\circledR}$. Thus, a fibrin clot is formed almost instantaneously with the Vivostat ${ }^{\circledR}$ system. 
However, the manufacturing techniques used by Vivostat ${ }^{\circledR}$ and CryoSeal ${ }^{\circledR}$ lack reproducibility with regard to mechanical properties and clinical outcomes. The fibrinogen synthesis rate varies according to numerous factors such as age, sex, alcohol use, BMI, tobacco use $(102,103)$.

Autologous fibrin glue can be produced in another way that is faster $(30 \mathrm{~min})$ and cheaper (10 dollars $/ 10 \mathrm{~mL}$ of plasma): from pooled plasma (at least eight donors), precipitating fibrinogen by protamine sulfate. This manufacturing method can yield $100 \%$ of the fibrinogen contained in the plasma. The fibrinogen thus harvested has been shown to be entirely clottable, and anti-fibrinolytic agents did not affect the tensile strength and adhesive strength of the fibrin clot. The tensile strength of this fibrin glue was found to be similar to that of Tisseel $^{\circledR}$ and adhesive strength was higher (because Tisseel ${ }^{\circledR}$ no longer contains F XIII after viral inactivation). The efficiency of this kind of glue is therefore fully satisfactory. A comparative study of protamine-fibrinogen concentrate versus Tisseel $^{\circledR}$ showed an improvement in blood loss and duration of bleeding using the former $(\mathrm{V}<0.05)(103)$.

\section{Characteristics}

After manufacturing, fibrin sealant obtained with the Vivostat ${ }^{\circledR}$ system contains low amounts of fibrinogen, albumin, F XIII and tranexamic acid, but does not contain fibronectin or other clottable plasma protein, which is why late hemostasis and tensile strength are poorer compared with other fibrin sealants (104). Since the tranexamic acidcontaining formulation of autologous sealant is 10 $\mathrm{mM}$ as opposed to $605 \mathrm{mM}$ in Quixil ${ }^{\circledR}$, any risk of neurotoxicity should be avoided; however, there is no randomized neurosurgery assay to prove Vivostat $^{\circledR}$ safe. In addition, this tranexamic acid concentration appears not to be high enough to prevent premature clot lysis. Indeed, in vivo, fibrin clots obtained with both Vivostat ${ }^{\circledR}$ and CryoSeal ${ }^{\circledR}$ systems were partially liquefied after 24 hours and totally liquefied after 2 days. With Tissucol $^{\circledR}$, fibrin clots were partially liquefied at day 5 and totally liquefied at day 6 . To sum up, autologous fibrin glues offer lower fibrinogen and fibrin concentrations, less cross-linking of fibrin fibers, major batch-to-batch variability and poorer resistance to clot lysis compared with Tissucol ${ }^{\circledR}$ $(104,105)$.

Although fear of virus or prion transmission was the driver for the development of autologous fibrin sealants, it is important to note that bacterial transmission is not diminished with this kind of product (104). Autologous glues are still preferred, despite clinical contraindications or the orthopedic context (postoperative osteomyelitis if fibrin glue contaminated with S. epidermidis from patient is used). Several randomized assays were carried out on Vivostat ${ }^{\circledR}$, but few were entirely independent of the manufacturers (106-114). A study on prolonged pulmonary air leaks highlighted the efficacy of Vivostat ${ }^{\circledR}$, which decreased prolonged air leaks and the duration of chest tube drainage after lung volume reduction. Indeed, postoperative severity scores were significantly lower for patients treated with $\operatorname{Vivostat}^{\circledR}(p<0.001)$.

Only one comparative study focused on the features (Table V) and efficacy of Vivostat ${ }^{\circledR}$, CryoSeal $^{\circledR}$ and Tissucol $^{\circledR}$ (101). As fibrinogen concentration in the clot is directly linked to its tensile strength, the Vivostat ${ }^{\circledR}$ system appears to produce fibrin glue more efficiently than the CryoSeal $^{\circledR}$ system, but this remains unproved. However, the quality of the fibrin clot formed via the Vivostat ${ }^{\circledR}$ system remains inferior to that of Tissucol ${ }^{\circledR}$.

\begin{tabular}{lllll}
\hline \multicolumn{7}{l}{ Table 5. Autologous fibrin glues versus fibrin glues from pooled plasma } & TISSUCOL $^{\circledR}$ \\
\hline & & CRYOSEAL $^{\circledR}$ & VIVOSTAT $^{\circledR}$ & ++ \\
Fibrinogen & ALBUMIN & +++ & ++ & + \\
component & FIBRONECTIN & + & - & +++ \\
Thrombin & FIBRINOGEN & ++ & +++ & +++ \\
component & ALBUMIN & +++ & - & + \\
Fibrin concentration in the clot (mg/mL) & 9.94 & - & 45 \\
Anti-fibrinolytic agent & - & 16.35 & Aprotinin \\
\hline
\end{tabular}


Automatized production of autologous fibrin glue is rapid (30-45 min) and economic (7 euros for $30 \mathrm{mg} / 2 \mathrm{~mL}$ of fibrinogen). Initial investment is nearly 25,000 euros, but the cost is offset by the treatment of numerous massive hemorrhages. Moreover, the high price of fibrin glues from pooled plasma makes autologous fibrin sealants an attractive alternative; especially if large volumes are required (automatized systems are designed to prepare volumes greater than $100 \mathrm{~mL}$ ); nevertheless, quality and reproducibility of the method are not well controlled.

\section{CONCLUSION}

Fibrin glues have proved their efficacy in hemostasis, as they mimic the last step of blood clotting. Since the qualitative and quantitative composition of commercially available products differs, their efficiency (tensile strength, elasticity, release kinetics, required volume) differs with the type of fibrin sealant. Moreover, studies show the major role played by F XIII in these sealants' efficacy. To achieve optimum results, each individual situation needs to be evaluated to identify the most suitable glue for each individual patient and surgery.

Although the indications for fibrin glue are currently limited to enhancing hemostasis in surgery, assays emphasize its value as a drug delivery system (for growth factors, stem cells and medicines), improving drug action in the target area. The findings of several studies comparing fibrin glue containing a drug versus the drug alone support this use of fibrin sealant. As for platelet-rich fibrins, their usefulness in tissue engineering is well established and widely reported (especially in chondrogenesis).

However, the presence of anti-fibrinolytic agents in most fibrin glues is an issue of concern, resulting in no improvement of fibrin clot quality, risk of hypersensitivity reactions (aprotinin) or neurological toxicity (tranexamic acid). On this issue, there are few studies involving fibrin glues (especially comparative studies) and some assays can be suspected of commercial bias. Consequently, further studies based on reliable data would be desirable.

Looking ahead, autologous fibrin sealants appear to present advantages compared with fibrin glues from pooled plasma, despite their slightly lower efficiency. Most notably, the risk of viral transmission is removed, since the receiver is his own blood donor. In addition, tolerance of autologous fibrin glues is better and they can be produced in larger quantities. However, data on autologous glues are currently insufficient, and new studies need to be undertaken.

\section{REFERENCES}

1. Gerhard Dickneite, Hubert Metzner, Thomas Pfeifer, et al. A comparison of fibrin sealants in relation to their in vitro and in vivo properties. Thrombosis Research, 112:73-82, 2003.

2. Gerhard Dickneite, Hubert Metzner, Monika Kroez, et al. The Importance of Factor XIII as a Component of Fibrin Sealants. J Surg Res, 107:186-195, 2002.

3. Kaan Kavakli. Fibrin glue and clinical impact on haemophilia care. Haemophilia, 5(6):392396, 1999.

4. Bernadette Tock, William N. Drohan, John R. Hess, et al. Haemophilia and advanced fibrin sealant technologies. Haemophilia, 4(4):449455, 1998.

5. Paula HB. Bolton-Maggs. The management of factor XI deficiency. Haemophilia, 4(4):683688, 1998.

6. Paula HB. Bolton-Maggs. Factor XI deficiency and its management. Haemophilia, 6(1):100-109, 2000.

7. Uri Martinowitz, David Varon, Michael Heim. The role of fibrin tissue adhesives in surgery of haemophilia patients. Haemophilia, 4(4):443448, 1998.

8. Thierry Burnouf, Mirjana Radosevichm, Hadi A.Goubran. Local Hemostatic Blood Products: Fibrin Sealant and Platelet Gel. The World Federation of Hemophilia, 36:1-10, 2004.

9. Roger Tredree, Wolfram Beierlein, Isabelle Debrix, et al. Evaluating the differences between fibrin sealants: recommendations from an international advisory panel of hospital pharmacists. The European Journal of Hospital Pharmacy Science, 12(1):3-9, 2006.

10. Ronald W. Busuttil. A comparison of antifibrinolytic agents used in hemaostatic fibrin sealants. J Am Coll Surg, 197:1021-1028, 2003.

11. Peter Agger, Jesper Langhoff, Morten $H$. Smerup, et al. Comparison between TachoComb and TachoSil for surgical hemostasis in arterial bleeding: an animal experimental study. J Trauma, 68(4):838-842, 2010.

12. Ulrich Eberhard, Martin Broder, Günther Witzke. Stability of Beriplast ${ }^{\circledR}$ P fibrin sealant: Storage and reconstitution. Int J Pharm, 313:1-4, 2006.

13. Committee for Medicinal Products for Human Use. Guideline on the clinical investigation of plasma derived fibrin sealant/haemostatic products. London: EMEA, 6p, 2004.

14. Lilliana Bar, Osnat Malka, Elvira Naboichenko, Israel Nur. The binding of fibrin sealant to collagen is influenced by the method of 
purification and the cross-linked fibrinogenfibronectin (heteronectin) content of the 'fibrinogen' component. Blood Coagul Fibrinolysis, 16:111-117, 2005.

15. Steven M Alston; Kenneth A Solen, Adam H Broderick, et al. New method to prepare autologous fibrin glue on demand. Translational Research, 149:187-195, 2007.

16. Richard R. Gammon, Nancy Avery, paul D. Mintz. Fibrin sealant: an evaluation of methods of production and the role of the blood bank. J Long Term Eff Med Implants, 8:103-116, 1998.

17. David H.Sierra. Fibrin sealant adhesive systems: a review of their chemistry, material properties and clinical applications. J Biomat Appl, 7:309352, 1993.

18. Moon Suh, Choong Ik Cha. Biochemical aspects of autologous fibrin glue derived from ammonium sulfate precipitation. Laryngoscope, 103:193-196, 1993.

19. Thomas H. Barker, Gerald M Fuller, Martine M. Klinger, et al. Modification of fibrinogen with poly(ethylene glycol) and its effects on fibrin clot characteristics. J Biomed Mater Res, 56:529-535.

20. Frederick H. Silver, Ming-Che Wang, George D. Pins. Preparation of Fibrin Glue: A Study of Chemical and Physical Methods. J Appl Biomater, 6:175-183, 1995.

21. Frederick H. Silver, Ming-Che Wang, George D. Pins. Preparation and use of fibrin glue in surgery. Biomaterials, 16:891-903, 1995.

22. Masafumi Kawamura, Makoto Sawafuji , Masazumi Watanabe, et al. Frequency of transmission of human parvovirus B19 infection by fibrin sealant used during thoracic surgery. Ann Thorac Surg, 73(4):1098-1100, 2002.

23. Masayuki Hino, Osamu Ishiko, Ken-ichi Honda, et al. Transmission of symptomatic parvovirus B19 infection by fibrin sealant used during surgery. Br J Haematol, 108(1):194-195, 2000.

24. Mark R. Jackson, Martin J. MacPhee, William N. Drohan, et al. Fibrin sealant: current and potential clinical applications. Blood Coagul Fibrinolysis, 7(8):737-746, 1996.

25. Thomas L. Matthew, William D. Spotnitz, Irving L. Kron, et al. Four years' experience with fibrin sealant in thoracic and cardiovascular surgery. Ann Thorac Surg, 50(1):40-43, 1990.

26. Alexander P. Reiner, Fibrin glue increasingly popular for topical surgical hemostasis. Lab. Med, 30:189-193, 1999.

27. Udaya Kumar, David M. Albala. Fibrin glue applications in urology. Curr Urol Rep, 2(1):7982, 2001.

28. Olivier Sterkers, Mohamed Badr el Dine, Maurice Bagot d'Arc, et al. Anastomosis of the facial nerve using fibrin glue, a propos of 60 cases. Rev Laryngol Otol Rhinol, 111(5):433435, 1990.
29. Alexis Bozorg Grayeli, Isabelle Mosnier, Nicolas Julien et al. Long-term functional outcome in facial nerve graft by fibrin glue in the temporal bone and cerebellopontine angle. Eur Arch Otorhinolaryngol, 262(5):404-407, 2005.

30. Vera Van Velthoven, Georg Clarici, Ludwig M Auer. Fibrin tissue adhesive sealant for the prevention of CSF leakage following transsphenoidal microsurgery. Acta Neurochir, 109:26-29, 1991.

31. Kyu Chang Lee, Sang Keun Park, Kyu Sung Lee. Neurosurgical application of fibrin adhesive. Yonsei Med, 32:53-57, 1991.

32. Živko Gnjidic, Damir Tomac, Lucijan Negovetic, et al. Fibrin sealants in the management of cerebrospinal fistulae. Biomed Prog, 7:39-42, 1994.

33. Kintomo Takakura, Osami Kubo, Yasuhiko Tajika, et al. Efficacy and safety of the use of BI 91.021.3 (Beriplast) in cranial nerve surgery. Shinryo Shinyaku, 31:1808-1817, 1994.

34. Can Solakoğlu, Mahir Mahiroğulları, Selami Cakmak, et al. Fibrin sealant in the treatment of acute ruptures of the Achilles tendon: long-term results. Eklem Hastalık Cerrahisi, 21(3): 124129, 2010.

35. R. Justin Thoms, Scott E. Marwin. The role of fibrin sealants in orthopaedic surgery. J Am Acad Orthop Surg,17(12):727-736, 2009.

36. Myron Schwartz, Juan Madariaga, Ryutiao Hirose, et al. Comparison of a new fibrin sealant with standard topical haemostatic agents. Arch Surg, 139:1148-1154, 2004.

37. Abe Fingerhut, Nicolas Veyrie, Toufik Ata, et al. Use of sealants in pancreatic surgery: critical appraisal of the literature. Dig Surg, 26(1):7-14, 2009.

38. Héctor D. González, Joan Figueras . Topical hemostatic devices in surgery: between science and marketing.Cir Esp, 85(1):23-28, 2009.

39. Takahiro Kinoshita, Shinichiro Miyoshi, Takaomi Suzuma T, et al. Intrapleural administration of a large amount of diluted fibrin glue for intractable pneumothorax. A clinical study based on 57 cases: including 2 unsuccessful cases. Jpn J Thorac Cardiovasc Surg, 51(2):41-47, 2003.

40. Shikha Sarkar, Naveed Hussain, Victor Herson. Fibrin glue for persistent pneumothorax in neonates. J Perinatol, 23(1):82-84, 2003.

41. Masatoshi Kurihara, Hideyuki Kataoka, · Aki Ishikawa, et al. Latest treatments for spontaneous pneumothorax. Gen Thorac Cardiovasc Surg, 58(3):113-119, 2010.

42. José Alcorta, Richard Audry, Cécile Cousté, et al. Collage dans le médical: Zoom sur les applications «In Vivo». Innovalis Collage Actualités, 81:1-8, 2010.

43. Anne Y. Abaut. 17èmes journées nationales sur les dispositifs médicaux. Revue des substances 
hémostatiques chirurgicales, 2007 oct, Nantes, France.

44. Nur Israel, Yacov Lyahovetsky, Liliana Bar, et al. Commercial fibrin sealants are not equivalent in a rabbit liver-resection model which quantitatively evaluates hemostasis and formation of adhesions. Eur Surg Res, 37(3):159-165, 2005.

45. GJ Wang, David S. Hungerford, Carlton G. Savory, et al. Use of fibrin sealant to reduce bloody drainage and hemoglobin loss after total knee arthroplasty: a brief note on a randomized prospective trial. J Bone Joint Surg Am, 83:1503-1505, 2001.

46. Martin P Sintler, Asif Mahmood, Simon RG Smith, et al. Quixil surgical sealant in carotid endarterectomy with ePTFE patch reconstruction. World J Surg, 29(10):12591262, 2005.

47. Anthony J. Rousou, Sidney Levitsky, Lorenzo Gonzalez-Lavin, et al. Randomized clinical trial of fibrin sealant in patients undergoing resternotomy or reoperation after cardiac operations. A multicenter study. J Thorac Cardiovasc Surg, 97:194-203, 1989.

48. Stefano Olmi, Alberto Scaini, Luigi Erba, et al. E. Use of fibrin glue (Tissucol) as a hemostatic in laparoscopic conservative treatment of spleen trauma. Surg Endosc, 21(11):2051-2054, 2007.

49. Francesco La Torre, Giuseppe Pascarella, Alessia P. Nicolai, et al. Use of human fibrin glue (Tissucol) in the treatment of recurrent fistulas. G Chir, 16(5):257-258, 1995.

50. Christopher J. Dunn, Karen L. Goa. Fibrin sealant: a review of its use in surgery and endoscopy. Drugs, 58: 863-886, 1999.

51. Andreas Rickenbacher, Stefan Breitenstein, Mickael Lesurtel, et al. Efficacy of TachoSil a fibrin-based haemostat in different fields of surgery--a systematic review. Expert Opin Biol Ther, 9(7):897-907, 2009.

52. William L. Hickerson, Israel Nur, Roberto Meidler. A comparison of the mechanical, kinetic, and biochemical properties of fibrin clots formed with two different fibrin sealants. Blood Coagul Fibrinolysis, 22(1):19-23, 2011.

53. Roderick T. Chalmers Darling Iii, et al. Randomized clinical trial of tranexamic acidfree fibrin sealant during vascular surgical procedures. Br J Surg, 97(12) :1784-1789, 2010.

54. Shepherd G. Pryor, Jonathan Sykes, Travis T. Tollefson. Efficacy of fibrin sealant (human) (Evicel) in rhinoplasty: a prospective, randomized, single-blind trial of the use of fibrin sealant in lateral osteotomy. Arch Facial Plast Surg, 10(5):339-344, 2008.

55. Naoki Minato, Yuji Katayama, Junji Yunoki. Hemostatic Effectiveness of a New Application Method for Fibrin Glue "The Rub-And-Spray Method" in Emergency Aortic Surgery for
Acute Aortic Dissection. Ann Thorac Cardiovasc Surg, 15(4):265-271, 2009.

56. Louise Z. Wang, Jed Gorlin, Sarah E. Michaud, et al. Purification of Salmon Clotting Factors and Their Use as Tissue Sealants. Thromb Res, 100:537-548, 2000.

57. Abha Sahni, Charles W. Francis. Vascular endothelial growth factor binds to fibrinogen and fibrin and stimulates endothelial cell proliferation, Blood, 96(12):3772-3778, 2000.

58. Isabelle Catelas, Joseph F Dwyer, Sam Helgerson. Controlled release of bioactive transforming growth factor beta-1 from fibrin gels in vitro, Tissue Eng Part C Methods. 14(2):119-128, 2008.

59. Abha Sahni, Tatjana Odrljin, Charles W. Francis. Binding of basic fibroblast growth factor to fibrinogen and fibrin, J Biol Chem, 273:7554-7559, 1998.

60. Phil G. Campbell, Susan K. Durham, James D. Hayes, et al. Insulin-like growth factor-binding protein-3 binds fibrinogen and fibrin, J Biol Chem, 274: 30215-30221, 1999.

61. Catalina Wong, Elisabeth Inman, Reiner Spaethe, et al. Fibrin-based biomaterials to deliver human growth factors, Thromb Haemost, 89:573-582, 2003.

62. Jan C. Becker, Wolfram Domschke, Thorsten Pohle. Biological in vitro effects of fibrin glue: fibroblast proliferation, expression and binding of growth factors, Scand J Gastroenterol, 39:927-932, 2004.

63. Shao-ping Nie, Wang Xiao, Qiao Shi-bin, et al. Improved myocardial perfusion and cardiac function by controlled-release basic fibroblast growth factor using fibrin glue in a canine infarct model. Journal of Zhejiang UniversityScience B (Biomedecine \& Biotechnologie), 11(12): 895-904, 2010.

64. Amgad M. Haleem, Abdel A. Singergy, Dina Sabry, et al. The Clinical Use of Human Culture-Expanded Autologous Bone Marrow Mesenchymal Stem Cells Transplanted on Platelet-Rich Fibrin Glue in the Treatment of Articular Cartilage Defects: A Pilot Study and Preliminary Results. Cartilage, 1(4):253-261, 2010.

65. Boaz Mizrahi, Christopher Weldon and Daniel S. Kohane. Tissue Adhesives as Active Implants. Stud Mechanobiol Tissue Eng Biomater, 8:39-56, 2011.

66. Xiao Zhibo, Zhang Miaobo. Effect of SustainedRelease Lidocaine on Reduction of Pain after Subpectoral Breast Augmentation. Aesthetic Surg J, 29:32-34, 2009.

67. Shin-ichiro Kitajiri, Keisaku Tabuchi, Harukazu Hiraumi, et al. Relief of post-tonsillectomy pain by release of lidocaine from fibrin glue. Laryngoscope, 111(4 Pt 1):642-644, 2001.

68. Katsuhiro Fujimoto, Keiko Yamamura, Takashi Osada, et al. Subcutaneous tissue distribution of 
vancomycin from a fibrin glue/Dacron graft carrier. Inc. J Biomed Mater Res, 36: 564-567, 1997.

69. Shinji Miyamoto, Tetsuo Hadama, Hideyuki Tanaka, et al. MRSA Aortic Valve Endocarditis Treated by Pericardium-lined Dacron Patch and Vancomycin-Containing Fibrin Glue. Case report. Ann Thorac Cardiovasc Surg, 10:252254, 2004.

70. Piero Marone, Vincenza Monzillo, Çatia Segù, et al. Antibiotic-impregnated fibrin glue in ocular surgery: in vitro antibacterial activity. Ophthalmologica, 213(1):12-15, 1999.

71. Hidenori Kitazawa, Hitoshi Sato, Isao Adachi, et al. Microdialysis assessment of fibrin glue containing sodium alginate for local delivery of doxorubicin in tumor-bearing rats. Biological and Pharmaceutical Bulletin 20(3): 278-281, 1997.

72. Hisahiro Yoshida, Yasuhiro Yamaoka, Mizuya Shinoyama, et al. Novel Drug Delivery System Using Autologous Fibrin Glue-Release Properties of Anti-cancer Drugs-Biological and Pharmaceutical Bulletin 23 (3): 371-374, 2000.

73. Oscar K Lee. Fibrin Glue as a Vehicle for Mesenchymal Stem Cell Delivery in Bone Regeneration. Journal of the Chinese Medical Association, 71(2):59-61, 2008.

74. Frédéric Braccini, Ehrenfest DM. Dohan. De l'intérêt du Platelet Rich Fibrin (PRF) de Choukroun au cours de la lipostructure faciale esthétique de Coleman : résultats préliminaires. Rev Laryngol Otol Rhinol, 128(4):255-260, 2007.

75. Charles Volpei, Henri Sabatier. Facial aesthetic lipostructure. Rev Laryngol Otol, 127(1-2):5156, 2006.

76. Y Xu, YF Song, ZX Lin. Transplantation of muscle-derived stem cells plus biodegradable fibrin glue restores the urethral sphincter in a pudendal nerve-transected rat model. Braz J Med Biol Res, 43(11):1076-1083, 2010.

77. Stephen Zoegall. Society for the Advancement of Blood Management study shows advantages of fibrin sealant over manual compression. J Vasc Nurs, 26(1):5, 2008.

78. Mario Testini, Germana Lissidini, Elisabetta Poli, et al. A single-surgeon randomized trial comparing sutures, N-butyl-2-cyanoacrylate and human fibrin glue for mesh fixation during primary inguinal hernia repair. Can J Plast Surg, 53(3):154-160, 2010.

79. Giampiero Campanelli, Diego Pettinari, Marta Cavalli. A modified Lichtenstein hernia repair using fibrin glue. Journal of Minimal Access Surgery, 2(3):129-133, 2006.

80. Pramod T. Shinde. Fibrin Sealant versus Use of Tackers for Fixation of Mesh in Laparoscopic Inguinal Hernia Repair. World Journal of Laparoscopic Surgery,2(1):42-48, 2009.
81. Paulo Negro, Francesco Basile, Antonio Brescia, et al. Open tension-free Lichtenstein repair of inguinal hernia: use of fibrin glue versus sutures for mesh fixation. Hernia, 15:714,2011

82. Grozdana Bilic, Carrie Brubaker, Phillip B Messersmith, et al. Injectible candidate sealants for fetal membrane repair: Bonding and toxicity in vitro. Am J Obstet Gynecol, 202(1): 851-859, 2010.

83. Roland Devlieger, Lynnae K. Millar, Gillian Bryant-Greenwood, et al. Fetal membrane healing after spontaneous and iatrogenic membrane rupture: A review of current evidence. Am J Obstet Gynecol, 195(6):15121520, 2006.

84. François Pigot, Laurent Siproudhis. Fistules anales et colle biologique. Le Courrier de coloproctologie (IV), $4: 117-119,2003$.

85. Daniel C. Damin, Mário A. Rosito, Paulo C. Contu. Fibrin glue in the management of complex anal fistula. Arq Gastroenterol, 46(4):300-304, 2009.

86. Jean Charles Grimaud, Nicolas MunozBongrand, Laurent Siproudhis, et al. Gastroenterology, 138(7):2275-2281, 2010.

87. Saliha Karagöz Avci, Serdar Yüceyar, Erman Aytaç. Comparison of classical surgery and sutureless repair with DuraSeal or fibrin glue for duodenal perforation in rats. Ulus Travma Acil Cerrahi Derg, 17(1): 9-13, 2011.

88. Bijan S. Kheirabadi, Rebecca Pearson, David Tuthill, et al. Comparative study of the hemostatic efficacy of a new human fibrin sealant: is an antifibrinolytic agent necessary? J Trauma, 52(6):1107-1115, 2002.

89. Micheline Berruyer, Jean Amiral, Patrick French, et al. Immunization by bovine thrombin used with fibrin glue during cardiovascular operations. Development of thrombin and factor $\mathrm{V}$ inhibitors. J Thorac Cardiovasc Surg, 105(5):892-897, 1993.

90. Hans Bänninger, Theres Hardegger, Andreas Tobler, et al. Fibrin glue in surgery: frequent development of inhibitors of bovine thrombin and human factor V. Br J Haematol, 85(3):5285321993.

91. Sara J. Israels. Development of antibodies to bovine and human factor $\mathrm{V}$ in two children after exposure to topical bovine thrombin. Am J Pediatr Hematol Oncol, 16(3):249-254, 1994.

92. Christophe Leroy-Matheron, Ariane Mallat, Christophe Duvoux, et al. Inhibitor against coagulation factor $\mathrm{V}$ after liver transplantation. Transplantation, 68(7):1054-1056, 1999.

93. James L. Zehnder, Lawrence L. Leung. Development of antibodies to thrombin and factor $\mathrm{V}$ with recurrent bleeding in a patient exposed to topical bovine thrombin. Blood, 76(10):2011-2016, 1990. 
94. Wolfram Beierlein, Albertus M. Scheule, Wulf Dietrich, et al. Forty years of clinical aprotinin use: a review of 124 hypersensitivity reactions. Ann Thorac Surg, 79:741-748, 2005.

95. Anne-Marie Oswald, Luc-Marie Joly, Charles Gury, et al. Fatal intraoperative anaphylaxis related to aprotinin after local application of fibrin glue. Anesthesiology, 99: 762-763, 2003.

96. Albertus M. Scheule, Wolfram Beierlein, Hans P. Wendel, et al. Aprotinin in fibrin tissue adhesives induces specific antibody response and increases antibody response of high-dose intravenous application. J Thorac Cardiovasc Surg, 118:348-358, 1999.

97. Yuzaburo Kanazawa, Shun Sato, Naotaka Iwamoto. Allergic reaction Following Arachnoid Plasty With a Fibrin Sealant. Neurol Med Chir, 50:608-610, 2010.

98. Walter Furst, Asmita Banerjee, Heinz Redl. Comparison of structure, strength and cytocompatibility of a fibrin matrix supplemented either with tranexamic acid or aprotinin. J Biomed Mater Res B Appl Biomater, 82(1):109-114, 2007.

99. Catherine M. Pipan, William P. Glasheen, Thomas L. Matthew, et al. Effects of antifibrinolytic agents on the life span of fibrin sealant. Abstract. J Surg Res, 53(4):402-407, 1992.

100. Joost de Vries, Tomas Menovsky, Sander van Gulik, et al. Histological Effects of Fibrin Glue on Nervous Tissue. Surg Neurol, 57:415-422, 2002.

101. Christoph Buchta, Hans Christian Hedrich, Maria Macher, et al. Biochemical characterization of autologous fibrin sealants produced by CryoSeal and Vivostat in comparison to the homologous fibrin sealant product Tissucol/Tisseel. Biomaterials, 26:62336241, 2005.

102. Jose L. Velada, Derek A. Hollingsbee, Alan R. Menzies, et al. Reproductibility of the mechanichal properties of Vivostat $^{\circledR}$ system patient-derived fibrin sealant. Biomaterials, 23:2249:2254, 2002.

103. Steven M. Alston, Kenneth A. Solen, Sivaprasad Sukavaneshvar, et al. In Vivo Efficacy of a New Autologous Fibrin Sealant. J Surg Res, 146:143-148, 2008.

104. Christoph Buchta, Markus Dettke, Philipp T Funovics, et al. Impact of manufacturing, irradiation and filtration steps to bacterial contamination of autologous fibrin sealant. Biologicals, 32:162-169, 2004.
105. Mauro Valbonesi. Fibrin glues of human origin. Best Pract Res Clin Haematol, 19(1):191-203, 2006.

106. Marco Gipponi, Giuliano Reboa, Tommaso Testa, et al. Tension-free primary closure with autologous platelet gel versus Vivostat- for the definitive treatment of chronic sacrococcygeal pilonidal disease. In Vivo, 24(4):583-589, 2010.

107. Elizabeth Belcher, Michael Dusmet, Simon Jordan, et al. A prospective, randomized trial comparing BioGlue and Vivostat for the control of alveolar air leak. J Thorac Cardiovasc Surg, 140(1):32-38, 2010.

108. Alessandra Picardi, Alessandro Lanti, Laura Cudillo, et al. Platelet gel for treatment of mucocutaneous lesions related to graft-versushost disease after allogeneic hematopoietic stem cell transplant. Transfusion, 50(2):501-506, 2010.

109. Michael R. Lassen, Søren Solgaard, Anne G. Kjersgaard, et al. A pilot study of the effects of Vivostat patient-derived fibrin sealant in reducing blood loss in primary hip arthroplasty. Clin Appl Thromb Hemost, 12(3):352-357, 2006.

110. Ali Belboul, Leif Dernevik, Obaid Aljassim et al. The effect of autologous fibrin sealant (Vivostat) on morbidity after pulmonary lobectomy: a prospective randomised, blinded study. Eur J Cardiothorac Surg, 26(6):11871191, 2004.

111. John B. Hanks, Henrik K. Kjaergard, Derek A. Hollingsbee. A comparison of the haemostatic effect of Vivostat patient-derived fibrin sealant with oxidised cellulose (Surgicel) in multiple surgical procedures. Eur Surg Res, 35(5):439444, 2003.

112. Henrik K. Kjaergard, Horace R. Trumbull. Bleeding from the sternal marrow can be stopped using vivostat patient-derived fibrin sealant. Ann Thorac Surg. 69(4):1173-1175, 2000.

113. Henrik K. Kjaergard, Horace R. Trumbull. Vivostat system autologous fibrin sealant: preliminary study in elective coronary bypass grafting. Ann Thorac Surg, 66(2):482-486, 1998.

114. Claus Moser, Isabelle Opitz, Wei Zhai, et al. Autologous fibrin sealant reduces the incidence of prolonged air leak and duration of chest tube drainage after lung volume reduction surgery: A prospective randomized blinded study. J Thorac Cardiovasc Surg, 136 (4):843-849, 2008. 